\title{
Differentiation Strategy of Ib Hashanah Card on the Decision of Selection of Sharia Credit Card Products with Analytic Hierarchy Process Method (BNI Syariah Case Study)
}

\author{
Popon Srisusilawati ${ }^{1}$, Asep Ramdan Hidayat ${ }^{2}$, Nanik Eprianti ${ }^{3}$, Ajeng Tri \\ Nurrahmawati $^{4}$ \\ \{po2nss@gmail.com¹, Asepramdanhidayat36764@gmail.com², Nanikeprianti@gmail.com³ \\ 1,2,3,4 Bandung Islamic University Jl. Tamansari No.1, Bandung 40116, Indonesia
}

\begin{abstract}
The research objective is to determine the implementation system, product differentiation strategy of sharia credit card products. Methodologically, this research used a qualitative method with primary and secondary data sources. Data collection techniques in the form of questionnaires to customers using iB Hashanah Card. Data processing techniques using the AHP method. The first research result, iB Hasanah Card is a system of implementation by DSN-MUI Number 54, the product differentiation strategy uses four indicators, namely Features, Product Adjustment, Quality of Conformity, and Easily Improved. Third, analysis of differentiation strategies for iB Hasanah Card Classic products, Gold, and Platinum on the decision to choose sharia credit card products using the AHP method resulting from Synthesis with Formula to Goal that has been processed through selection experts with inconsistency value of 0.06 for the results of excellence owned by iB Hasanah Card Gold.
\end{abstract}

Keywords: Sharia Credit Cards, Differentiation Strategies, AHP

\section{Introduction}

According to Bank Indonesia (BI) payment statistics data quoted by CNBC Indonesia, the total credit card transactions reached Rp. 297.4 trillion over the past year, with a transaction volume of 326.9 billion[1], it means that the development of credit card usage is increasing because there are many conveniences obtained from the use of credit cards. In addition to the convenience in submitting applications, credit cards have many benefits for users, especially for those who frequently travel, both for business and travel because credit cards are acceptable to make transactions in various countries.[2]

Credit cards are not only issued in conventional banks, but several sharia banks have also issued. BNI Sharia as one of the sharia banks issued credit cards, namely iB Hashanah Card. iB Hasanah Card can be used to shop both domestically and overseas, to purchase various merchants, withdraw cash through ATMs, pay various bills (electricity, water, telephone, cable tv, tuition fees payment), to purchase plane tickets and other facilities as quickly as a credit card. It is because Master Card International also supports the iB Hasanah Card. Thus, it used at nearly 30 million merchants, and ATMs marked with Master Card or Cirrus logo worldwide [3].

BNI Syariah issues three types of iB Hasanah Card, namely: iB Hasanah Card Classic; iB Hasanah Card Gold; and iB Hasanah Card Platinum. Some significant differences between the three credit cards lie in the credit card limit and monthly membership fee. These 3 three credit 
card products will undoubtedly be a big responsibility for BNI Syariah, especially in maintaining each of its products, so that these products can survive and are always in demand by potential customers of credit card users[4]. With the right promotion or marketing techniques, banks are expected to overcome competition, thereby increasing productivity and income[5].

To be able to improve and retain customers consider to provide different values and satisfaction and to give different characteristics to the products owned by competing products. The differentiation is one of the essential strategies in a company's marketing plan, where the company must have a differentiator that is characteristic of the company itself that will be an attraction for customers. The differentiation strategy also interpreted as a company's effort to differentiate its products between one product and another in a trait that makes it more desirable.

According to Philip Kotler and Kevin Lane Keller explained that a product could be differentiated to include several indicators, including features, adjustments, conformance quality, and Repairability. When linked to sharia credit card products, these indicators can identify, select, describe, display and package products for customers by creating complicated product features for competitors to imitate. Furthermore, the product can survive, remain attractive to potential customers, and under the product expected by credit card user customers[6].

Nowadays, some Islamic banks are not able to maintain their credit card products. Recently, there are only two banks that still keep issuing the sharia credit card, which are BNI Syariah and CIMB Niaga Syariah banks[7]. It means that some banks experience problems in running these products. Thus, they cannot maintain the product. However, BNI Syariah bank still consistent in maintaining $\mathrm{iB}$ Hasanah Card during this problem. Consequently, its existence recognised in the community who feel the need for sharia-based credit cards to provide convenience and security in transactions in this modern era[3].

In the competition of banking business world, several reasons are considered by customers to choose a product. The customer's decision in choosing a product would be more than one choice for product decision making, and it means that there must be other alternatives to take when someone makes a decision[8]. Customer decision making in selecting products is the process of finding information, evaluating and selecting several product alternatives, selecting between a distribution, and implementing decisions on products to be used or chosen by customers[9]. In the decision-making process, customers have goals or behaviours that they want to achieve to achieve these goals. Thus, it can help in choosing which products will be taken by customers and can use the Analytical Hierarchy Process (AHP) method.

\section{Theoretical Basis}

\section{Sharia Credit Card}

Sharia card is a card that functions like a credit card with a legal relationship (based on an existing system) between the parties based on sharia principles[2]. Although the functions of the sharia card are the same as a credit card, the sharia card untreated as identical interest as usury. Therefore, the sharia card uses a contract mechanism based on sharia principles. The contracts used in sharia cards are kafalah, qardh, and ijarah. The advantages of Islamic credit cards include[7]:

1. Interest-free, because it uses the principles of sharia and the contracts used are also under Islamic law. 
2. Cheaper, the concept of costs arising from Islamic credit cards is cheaper than conventional credit cards.

3. The functions are same as a credit card, which can be used to shop for a variety of needs, goods, and particular services for card users with a worldwide master card network, which makes Islamic credit cards accepted in all Mastercard reckons throughout the world

4. Concerned with others, this is designated by the late form of fines for payments that do not book as bank profits, but the funds are directed for social and humanitarian interests through leading social institutions[10]

\section{Differentiation Strategy}

In general, there are three potentially successful strategies to outperform companies in an industry. These strategies include the Cost Excellence Strategy (Low-Cost Strategy), the Differentiation Strategy (Differentiation Strategy), and the Focus Strategy (Focus Strategy)[11]. Of the three strategies, the differentiation strategy is the most profitable. Because the differentiation strategy is based on offering customers a value that is not owned by a competitor[6]. The differentiation strategy parameters include:

1. Feature

Most products can be offered by varying features and providing characteristics that complement the essential functions of the product. Companies can identify and choose the right new features by surveying the latest buyers and then calculating the comparison of customer value with company costs for each potential feature.

2. Adjustment

Can differentiate products by adjusting the product to individual desires.

3. Quality of Conformity

Buyers expect the product to have high conformance quality, which is the level where all units produced are identical and meet the promised specifications.

4. Easy to repair (Repairability)

It means a measure of convenience to repair the product when the product is damaged whose size can be seen through the value and time-used.

From the explanation above, the authors conclude that these indicators are potential to be distinguished.

\section{Differentiation Strategy}

In general, there are three potentially successful strategies to outperform companies in an industry. These strategies.

\section{Decision Making}

The consumer decision-making process is a necessary psychological process that plays an essential role in understanding how consumers make purchasing decisions[12][4]. Consumer decision making in buying is a process of problem recognition, information seeking, evaluation (evaluation) and selection of alternative products, selection between distribution and implementation of decisions on products to be used or purchased by consumers[13][14]. 


\section{Discussion}

\section{1. iB Hasanah Card Classic Product Implementation System, iB Hasanah Card Gold, and iB Hasanah Card Platinum at BNI Syariah}

iB Hasanah Card is a sharia-based financing card that has the same functions as a credit card but uses sharia principles with the provisions of the National Sharia Board Number 54 / DSN-MUI / X / 2006, where there is no interest on transactions that occur. This card was created to facilitate the payment system and as collateral for every purchase of goods and services that function in every place marked MasterCard.

The lake of interest in the iB Hasanah Card has become a distinct advantage for BNI Syariah because it will attract the interest of the public to use the iB Hasanah Card considering that majority of Indonesian Muslim people hold the principle of caution, especially in conducting economic transactions. The public's desire for the provision of sharia-based credit cards is quite strong so that the growth of the sharia financial industry has also increased. Currently, iB Hasanah Card is issued because most activities are using credit cards payment system and have grown in every business sector. The implementation system of iB Hasanah Card Classic, iB Hasanah Card Gold, and iB Hasanah Card Platinum at BNI Syariah has been well implemented because in practice iB Hasanah Card provides many benefits and provides many conveniences for customers who use credit cards to make transactions. Judging from the type of contract used, it means that the iB Hasanah Card in its implementation is under the provisions of the National Sharia Board Number 54/DSNMUI/X/ 2006.

2. iB Hasanah Card Classic Product Implementation System, iB Hasanah Card Gold, and iB Hasanah Card Platinum at BNI Syariah

Product Differentiation Strategy for iB Hasanah Card Classic, iB Hasanah Card Gold, and iB Hasanah Card Platinum at BNI Syariah.

\subsection{1 iB Hasanah Card Classic}

iB Hasanah Card Classic is a credit card deemed very necessary to provide many conveniences when making transactions so that not only the middle class and above people can feel the presence of Islamic credit cards, but people with lower economic conditions can also obtain credit card facilities. So that the presence of iB Hasanah Card Classic will provide many benefits and provide opportunities for new users to be able to have an Islamic credit card.

\subsection{2 iB Hasanah Gold Card}

iB Hasanah Card Gold is a product that has many features provided through various promotions and discounts that are felt to be very attractive to credit card users, especially for users who frequently shop at various merchants who have collaborated with BNI Syariah. The majority of iB Hasanah Card Gold users are people who work as entrepreneurs who often conduct transactions to meet the needs of their business activities, with the many promotions and discounts provided by iB Hasanah Card Gold will undoubtedly help reduce the production costs of entrepreneurs so that it will provide many benefits for business people. 


\subsection{3 iB Hasanah Card Platinum}

iB Hasanah Platinum Card is an Islamic credit card that will be a solution for customers who often make large amounts of transactions without worrying about the minimum transaction limit because the limit given by iB Hasanah Card Platinum is quite large. This card is specifically for customers who have high incomes or have middle to upper socioeconomic status.

\section{Product Differentiation Strategy for iB Hasanah Card Classic, iB Hasanah Card Gold, and iB Hasanah Card Platinum for decisions on the selection of sharia credit card products using the Analytic Hierarchy Process (AHP) method}

Based on the results of the questionnaire to customers using iB Hasanah Card Classic, iB Hasanah Card Gold, and iB Hasanah Card Platinum, the researchers then determined the advantages of the iB Hasanah Card differentiation strategy related to the problems that have been found and the results of the quantification of the model from questionnaire. Data analysis of the research will be carried out when it has a value of the consistency/consistency ratio (CR) $<0.1$. If the $\mathrm{CR}$ value $>0.1$, then the informant will be repeated (judgment) by the informant. This consistency test calculation uses expert choice as follows:

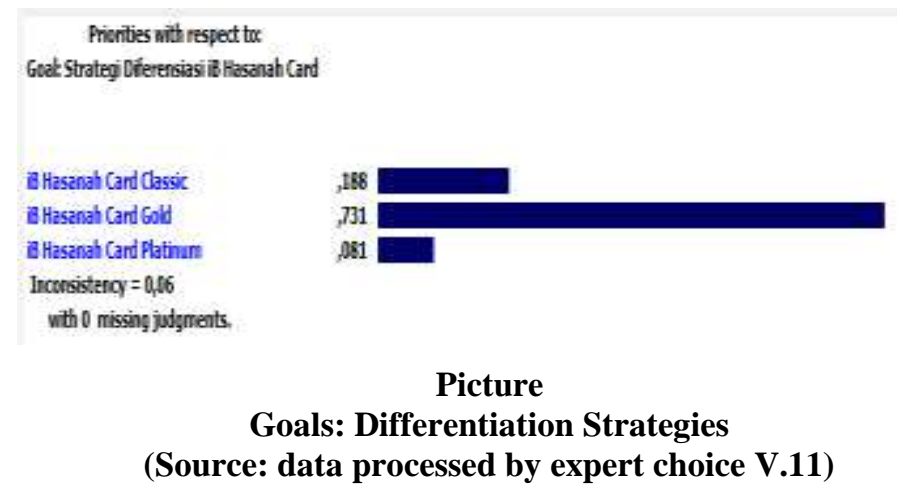

AHP data processing results state that the superiority of the differentiation strategy is found in the iB Hasanah Card Gold with a weight value of 0.731 and an Inconsistency value of 0.06 otherwise can be analysed. After doing the above stages, we get the superiority of each differentiation strategy for each product because the purpose of this study is to determine which products between iB Hasanah Card Classic, iB Hasanah Card Gold, and iB Hasanah Card Platinum are superior to the differentiation strategy. For more details, it can be seen in the table above about the value of the superiority of iB Hasanah Card differentiation strategy from the results of the questionnaire that has been processed by the application of expert choice.

Based on the results of the questionnaire to customers using iB Hasanah Card, the differentiation strategy undertaken by BNI Syariah is more focused on providing features through facilities and promos on each card. It means that the excellence created by the iB Hasanah Card is to stimulate customer interest and to retain its customers through various promotions which are different between iB Hasanah Card Classic, iB Hasanah Card Gold, and iB Hasanah Card Platinum. 
IB Hasanah Card differentiation strategy to customer decisions in choosing products through the Analytic Hierarchy Process (AHP) method with the Expert Choice application is the result of Synthesis with Respect to Goal. A very high priority is found in iB Hasanah Card Gold with an Inconsistency value of 0.06 , and this product has many features through the facilities and promos provided. One of the features is the provision of rewards in each transaction that later the reward can be exchanged with prizes without drawing during the Definite Bonus Program Period. iB Hasanah Gold Card also has a minimum transaction limit with a modest amount so that it can be reached by customers who have moderate, high socioeconomic status, or low socioeconomic status, it means that when viewed in terms of the four indicators of differentiation strategy (features, adjustments, conformity quality, and easy to repair) it has been mastered by iB Hasanah Card Gold both at the promotion stage and the implementation process. Therefore, the results of the questionnaire explained that the customer chose this product.

The three iB Hasanah Card products have their own characteristics and advantages, such as the iB Hasanah Card Classic with an Inconsistency value of 0.05 which has advantages in the adjustment indicators for differentiation strategies, iB Hasanah Gold Card with an Inconsistency value of 0.07 which has its own advantages in terms of features and providers of promos and facilities, while iB Hasanah Card Platinum with an Inconsistency value of 0.06 which has a slight balance between the features and product adjustments, it can be interpreted that the iB Hasanah Card is a very priority advantage if the product differentiation strategy refers to feature indicators and facility providers through attractive promos provided because customers get benefits and convenience when given attractive promos so that economic transaction activities are made very easy and fun.

\section{Conclusions}

The results of the study are based on the above discussion, and it can be concluded as follows:

1. The system of implementing iB Hasanah Card products uses sharia principles and is under the provisions of the National Sharia Board Number 54 / DSN-MUI / X / 2006, where there is no interest on transactions that occur. The absence of interest in the $\mathrm{iB}$ Hasanah Card product is a unique attraction for customers considering that in Indonesia the majority are Muslim and on the other hand the need for financial services will be easily provided by a credit card.

2. Product differentiation strategy is a way that can be done to give a characteristic to each product to increase the value of promotions to attract prospective customers and retain customers. Kotler and Keller explain four indicators that can be used to determine the advantages of product differentiation strategies, namely features, product adjustments, quality of conformity, and easy to improve. The three iB Hasanah Card products have their characteristics and advantages, which will undoubtedly determine the customer's interest in each product.

3. The results of data analysis through the Analytic Hierarchy Process (AHP) method with the Expert Choice application are the results of the Synthesis with Respect to Goal. Based on the three iB Hasanah Card products owned by BNI Syariah, a very high priority is found in the $\mathrm{iB}$ Hasanah Gold Card with an Inconsistency value of 0, 06 and the highest indicator is Features through facilities and promos given to customers with a weight value of 0.575 and an Inconsistency value of 0.07

Based on the conclusions above, from this study, the authors suggest several things: 
1. BNI Syariah is expected to be able to improve the differentiation strategy of each iB Hasanah Card product, considering that until now, there are not too many differences from each product. So that later iB Hasanah Card products, both Classic, Gold, and Platinum can be more attractive to prospective customers and retain customers.

2. The world of sharia banking has become more innovative and provides many opportunities for customers to enjoy various transactions facilities while prioritising Islamic values, not just getting convenience but making life more blessing by leaving things that Allah does not enjoy such as eating wealth usury. Islam is a dominant religion in Indonesia. Hopefully, more awareness will emerge, especially for the majority of Indonesian Muslims to support Islamic finance by using Islamic banks as a medium for transactions. Furthermore, Islamic banking can develop in the future and become the number one financial institution in Indonesia.

For further researchers, it is expected to be able to expand research on the phenomena and problems of Islamic banking aimed at improving the quality for future improvement. 


\section{References}

[1] CNBC, "No Title," https://www.cnbcindonesia.com/news/20180202144743-43364/masyarakat-belanja-pakai-kartu-kredit-rp-297-t-di-2018, 2018. .

[2] M. Hanifah, "Arah Kebijakan Hukum Politik Ekonomi," J. Ilmu Huk. Riau, vol. 3, no. $1,2012$.

[3] S. Hay, "STRATEGI KEUNGGULAN BERSAING PT BANK BNI SYARIAH CABANG DHARMAWANGSA SURABAYA DALAM MENINGKATKATKAN JUMLAH NASABAH," 2014.

[4] P. Srisusilawati, "KAJIAN KOMUNIKASI PEMASARAN TERPADU DALAM MENDORONG KEPUTUSAN PEMBELIAN JASA PERBANKAN," Amwaluna J. Ekon. dan Keuang. Syariah, vol. 1, no. 1, pp. 1-18, Jan. 2017.

[5] L. Penaloza, Marketing Management. 2013.

[6] P. Kotler and K. Keller, "Manajemen pemasaran," 2009.

[7] W. Azis, "Studi Deferensiasi Produk Kartu Kredit Syariah Antar Bank Syariah di Indonesia (Studi Kasus Pada Bank BNI Syariah dan CIMB Niaga Syariah)," 2015.

[8] A. Gampu, L. Kawet, Y. U.-J. E. J. Riset, and undefined 2015, “Analisis Motivasi, Persepsi, Dan Pengetahuan Terhadap Keputusan Nasabah Memilih PT. Bank Sulutgo Cabang Utama Manado," ejournal.unsrat.ac.id.

[9] I. Gede, T. Esa Widhiarta, and I. M. Wardana, "PENGARUH EKUITAS MEREK TERHADAP KEPUTUSAN PEMBELIAN IPHONE DI DENPASAR,” vol. 4, no. 4, pp. 832-848, 2015.

[10] H. F. Prayogo, "PERSEPSI ANALIS KARTU KREDIT TENTANG RESIKO KARTU KREDIT PADA BANK KONVENSIONAL DAN BANK SYARIAH," $J$. Akunt. Indones., vol. 3, no. 1, p. 59, Nov. 2016.

[11] M. Krisnamurti, G. D.-J. M. dan Bisnis, and undefined 2015, "STRATEGI DIFERENSIASI PRODUK DAN JASA DI INDUSTRI DIGITAL PRINT," journal.undiknas.ac.id.

[12] V. Z.-E. Y. N. I. S. Cet and undefined 2017, "Islamic Marketing Management."

[13] A. Munandar, "Psikologi industri dan organisasi," 2001.

[14] J. A.-J. P. Undip and undefined 2017, "Subjective Well-Being (Kesejahteraan Subjektive) Dan Kepuasan Kerja Pada Staf Pengajar (Dosen) Di Lingkungan Fakultas Psikologi Universitas Diponegoro," eprints.undip.ac.id. 